Available online at GSC Online Press Directory

GSC Biological and Pharmaceutical Sciences

e-ISSN: 2581-3250, CODEN (USA): GBPSC2

(RESEARCH ARTICLE)

\title{
The effect of ethanolic extract of Annona muricata leaf on the basal ganglia
}

\author{
Nweke Elizabeth Obioma ${ }^{1,{ }^{*}}$ and Akpuaka Frank Chinedu ${ }^{1,2}$ \\ ${ }^{1}$ Department of Anatomy, Faculty of Basic Medical Sciences, Chukwuemeka Odumegwu Ojukwu University, Anambra \\ State, Nigeria. \\ 2 Department of Anatomy, Faculty of Basic Medical Sciences, Abia State University, Uturu, Abia State, Nigeria.
}

Publication history: Received on 17 February 2019; revised on 05 March 2019; accepted on 08 March 2019

Article DOI: https://doi.org/10.30574/gscbps.2019.6.3.0025

\begin{abstract}
Annona muricata (Linn.) is an evergreen tropical tree of the Annonaceae family that possesses phytotherapeutic bioactive compounds known as annonaceous acetogenins effective for the treatment of cancers and several diseases. This study investigated the effect of ethanolic extract of Annona muricata leaf on the basal ganglia. Twenty four (24) adult wistar rats were randomly divided into four groups (A, B, C \& D) of six animals each. Group A served as the control and received $2 \mathrm{ml} / \mathrm{kg}$ of distilled water; the experimental groups B, C \& D were orally administered $100 \mathrm{mg} / \mathrm{kg}, 200$ $\mathrm{mg} / \mathrm{kg}$ and $300 \mathrm{mg} / \mathrm{kg}$ body weight of ethanolic extract of Annona muricata leaf respectively for thirty days. At the end of administration, the animals were anaesthetized under the influence of chloroform vapour, dissected and their brain harvested for histological examination. The histological result revealed mild increase in the number of basal ganglia nuclei cell body (BGNCB) and fibres (F) with mild necrosis of neurons when compared to their control group. In conclusion, high consumption of ethanolic extract of Annona muricata could result in extrapyramidal side effects. Thus, it should be taken at lower doses.
\end{abstract}

Keywords: Annona muricata; Basal ganglia; Wistar rats; Histology

\section{Introduction}

Medicinal plants have contributed so much in the treatment and management of various diseases and its use has expanded rapidly in both developed and developing countries [1]. This has been attributed to its affordability, accessibility and efficacy. However, the toxic effects of these medicinal plants are sometimes overlooked [2]. An example of medicinal plant considered useful is Annona muricata.

A. muricata commonly known as graviola or soursop, belongs to the member of Annonaceae family. It is widely distributed throughout the tropical and subtropical parts of the world, including India, Malaysia and Nigeria [3]. A. muricata is an evergreen, terrestrial, erect tree of about 5-8 $\mathrm{m}$ in height with large, glossy, dark green leaves. The edible fruits are heart-shaped and green in colour with a diameter between 15 and $20 \mathrm{~cm}$ [4]. The leaf, bark, root, stem, and fruit seed extracts of $A$. muricata have been reported to have anti-bacterial [5, 6], antifungal [7] and anti-malarial [8, 9] properties. Among the chemical constituents found in the leaf of $A$. muricata are alkaloids [10], essential oils [11] and acetogenins [12]. Acetogenins were found to be a promising new anti-tumor and anticancer agent [13] and demonstrated the ability to be selectively toxic against various types of cancerous cells without harming healthy cells [14]. However, many acetogenins are characterised by neurotoxicity of which an example is annonacin. Annonacin has been reported to be a potent neurotoxin that is associated with neurodegenerative disease [15].

\footnotetext{
${ }^{*}$ Corresponding author

E-mail address: nwekeelizabeth@yahoo.com
} 
Previous research has suggested that a connection between soursop consumption and atypical forms of Parkinson's disease is conceivable due to high concentrations of annonacin $[16,17]$. This research therefore aims to ascertain that fact.

\section{Material and methods}

\subsection{Breeding of animals}

Twenty four (24) male Wistar rats weighing between 180-200 g were procured from the animal house of the Department of Anatomy, Nnamdi Azikiwe University. The rats were kept in standard cages under normal temperature $\left(27-30{ }^{\circ} \mathrm{C}\right)$, with each cage having wire gauze for cross ventilation. The ethical committee of the College for animal care and use approved the study design in compliance with the National regulation for animal research. The animals were acclimatized for a period of two weeks before commencement of treatment. They were fed with normal rat chow and water ad libitium.

\subsection{Preparation of the extract}

Fresh leaves of $A$. muricata were procured from Uturu, Abia State. They were identified at the herbarium units of the Department of Botany, Abia State University Uturu, Abia State. The leaves were washed in a basin of water to remove dirt and dried under ambient temperature. The dried leaves were ground using laboratory blender to a coarse powdery form. $600 \mathrm{~g}$ of the powder was macerated in four (4) litres of ethanol, sealed and allowed for $48 \mathrm{hrs}$. After 48 hours, the mixture was sieved using a porcelain cloth and filtered using filter paper into a clean glass beaker. The filtrate was further dried using rotary evaporator into a jelly-like/paste-like form and stored in refrigerator for future use.

\subsection{Experimental design}

The twenty four (24) rats were weighed and randomly allocated into four (4) groups of six (6) animals. The groups were designated as group A, B, C, and D. Group A served as the control group and was administered $2 \mathrm{ml} / \mathrm{kg}$ body weight of distilled water. The experimental groups B, C, and D were administered with $100 \mathrm{mg} / \mathrm{kg}, 200 \mathrm{mg} / \mathrm{kg}$ and $300 \mathrm{mg} / \mathrm{kg}$ body weight of the extract of $A$. muricata respectively.

The administration was given orally between the hours of 10-11 am daily and lasted for thirty (30) days. Twenty four (24) hours after the last dose, the animals were anaesthetized by chloroform inhalation and dissected. The brain tissues were harvested and fixed in $10 \%$ formal saline for histological examination.

\subsection{Histopathological examination}

The brain tissues from the animals were fixed in $10 \%$ formal saline and were processed by passing them through ascending grades of alcohol. The tissues were then cleared in xylene after which embedding in paraffin wax was carried out. Rotatory microtome was used to obtain tissue sections of 3-5 $\mu \mathrm{m}$ thick. The sections were deparaffinised, hydrated and stained using haematoxylin and eosin (H\&E) dye. The sections were then mounted using neutral dibutylphthalate xylene (DPX) medium for microscopic examination at x150 magnification.

\section{Results and discussion}

\subsection{Histopathological analysis}

Photomicrograph sections of the basal ganglia of animals in group A (Figure 1) showed normal sub-cortical basal ganglia cell body (BGCB) and fibers (F). Group B (Figure 2) showed a mild increase in the number of basal ganglia nuclei cell body (BGNCB) and fibers (F). Group C (Figure 3) showed mild to moderate increase in the number of basal ganglia nuclei cell body (BGNCB) and fibers (F) while Group D (Figure 4) showed moderate increase in the number of basal ganglia nuclei cell body (BGNCB) and fibers (F) 

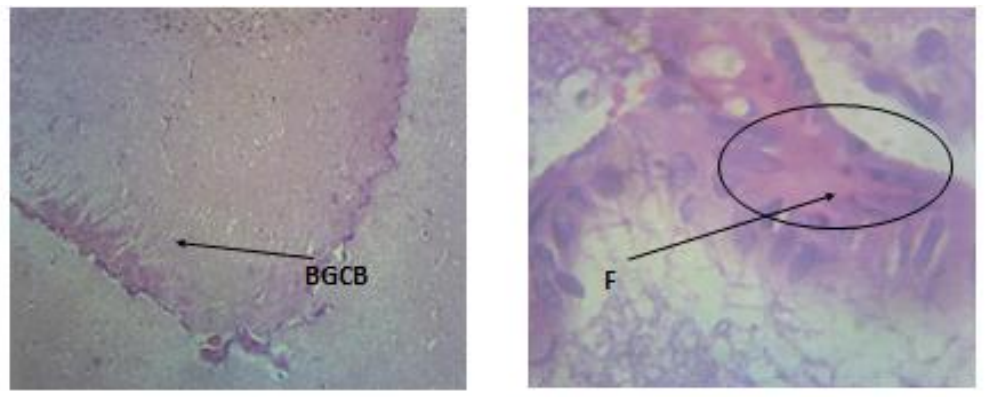

Figure 1 Photomicrograph section of group A basal ganglia showing normal sub-cortical basal ganglia cell body (BGCB) and the fibers (F)
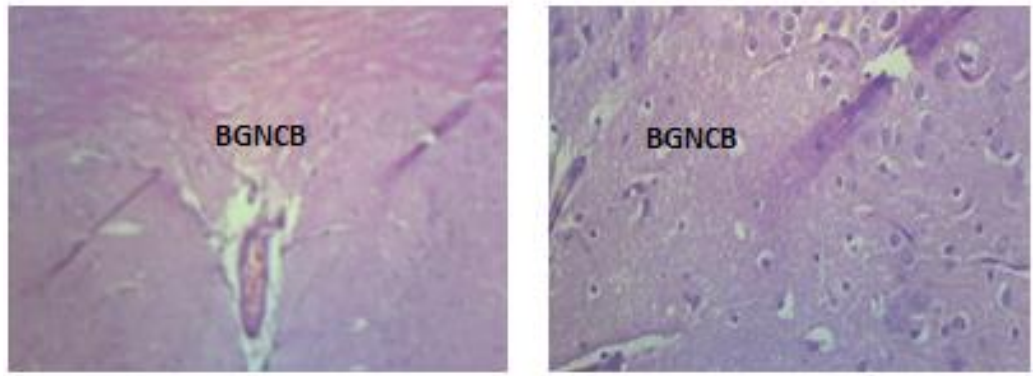

Figure 2 Photomicrograph section of group B basal ganglia administered with $100 \mathrm{mg} / \mathrm{kg}$ of A. muricata showing mild increase in the number of basal ganglia nuclei cell body (BGNCB) and fibers (F)
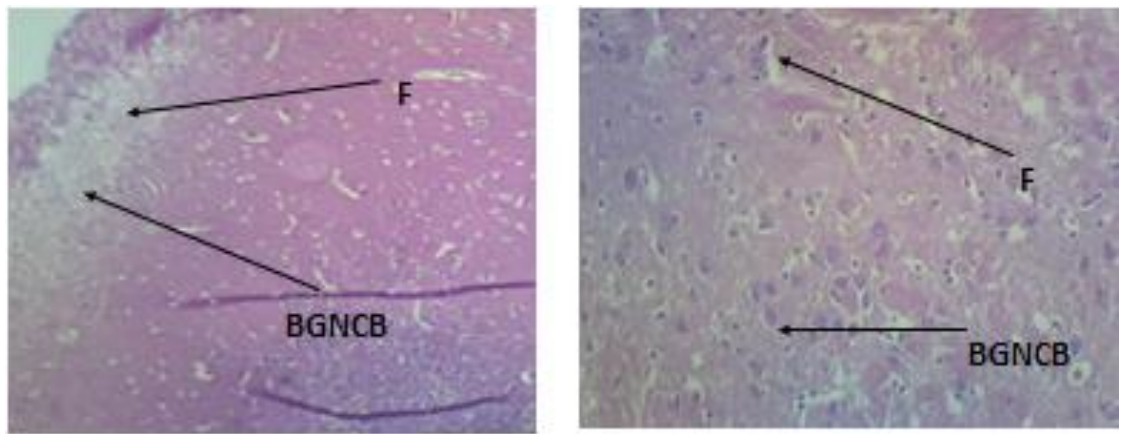

Figure 3 Photomicrograph section of group C basal ganglia administered with $200 \mathrm{mg} / \mathrm{kg}$ of A. muricata showing mild to moderate increase in the number of basal ganglia nuclei cell body (BGNCB) and fibers (F)
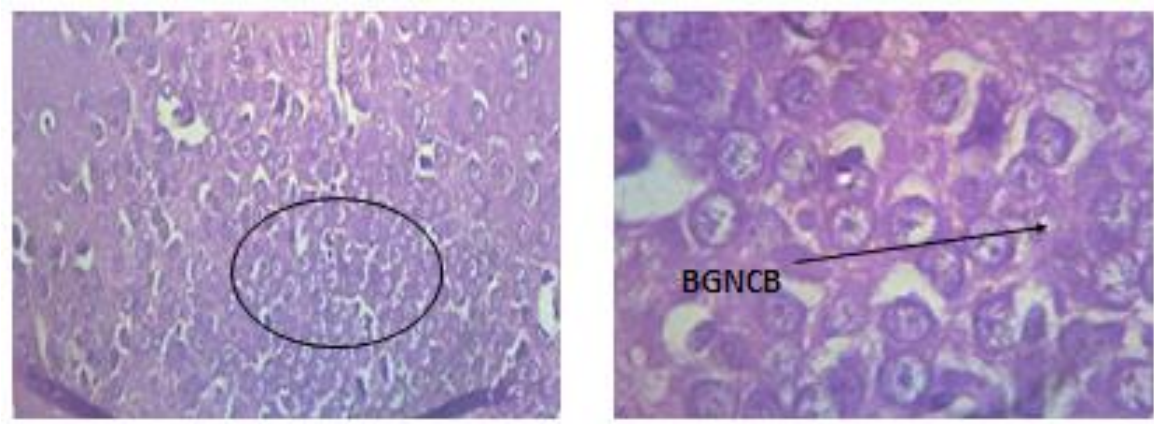

Figure 4 Photomicrograph section of group D basal ganglia administered with $300 \mathrm{mg} / \mathrm{kg}$ of $A$. muricata showing moderate increase in the number of basal ganglia nuclei cell body (BGNCB) and fibers (F)

Medicinal plants contain several phytochemical substances that are known to have healing properties. People without access to modern medicine rely mostly on these medicinal plants for treatment of diseases, as they are similar in terms of active compound. Annona muricata is evidently one of these beneficial medicinal plants known for its diverse 
biological activities [18] which also have its toxic effect. The basal ganglia control voluntary motor movement, eye movement, cognition and learning. Its dysfunction results in a wide range of neurological conditions.

The result of this study revealed an increase in the number of basal ganglia nuclei cell body (BGNCB), nerve fibres (F), cytoplasmic vacuolization of neurons and necrosis of neurons in the treated groups when compared to the control. These changes show that high doses of $A$. muricata extract is likely to damage the basal ganglia which could result in extrapyramidal Parkinsonism-like side effects. Necrosis in the substantia nigra was also evident and reached the stage of degeneration. This effect is understandable given the strength of acetogenin compounds in soursop plants. This acetogenin can passively diffuse into the cell and is fifty times more toxic to dopaminergic neurons and two thousand times more toxic to non-dopaminergic neurons, when compared with 1-methyl-4- phenylpyridinium (MPP) (19, 20]. Substantia nigra is rich in dopaminergic neuronal cell bodies and there is a possibility that the acetogenins in ethanolic extract of soursop leaf could preferentially affect non-dopaminergic neurons as compared to dopaminergic neurons. These results are consistent with that of Champy et al [20]. Previous research has suggested that a connection between soursop consumption and atypical forms of Parkinson's disease is conceivable due to high concentrations of annonacin $[16,17]$. This is in agreement with the outcome of this research.

\section{Conclusion}

Findings from this research reveal that high consumption of ethanolic extract of $A$. muricata could result in atypical forms of Parkinsonism. Therefore, its consumption should be regulated and taken at low doses.

\section{Compliance with ethical standards}

\section{Disclosure of conflict of interest}

There was no conflict of interest in the research of this work.

\section{Statement of ethical approval}

The experiment was carried out at Abia State University, Uturu with approval by the local ethics committee for animal care and use.

\section{References}

[1] Reddy KJ. (2004). Medicinal plant research scenario in India, Info concepts India Inc. International Journal of Pharma Sciences and Research, 1, 25-28.

[2] Keen RW, Deacon AC, Delves HT, Moreton JA and Frost PG. (1994): Indian herbal remedies for diabetes as a cause of lead poisoning. Postgraduate Medical Journal, 70, 113-114.

[3] Adewole SO and Caxton-Martins EA. (2006). Morphological changes and hypoglycemic effects of Annona muricata Linn. (Annonaceae) leaf aqueous extract on pancreatic B-cells of streptozotocin-treated diabetic rats. African Journal of Biomedical Research, 9, 173-187.

[4] De Souza R, Benassi E, da Silva RR, Afonso S and Scarminio IS. (2009). Enhanced extraction yields and mobile phase separations by solvent mixtures for the analysis of metabolites in Annona muricata L. Leaves. Journal of Separation. Science, 32, 4176-4185.

[5] Misas C, Hernández N and Abraham A (1979). Contribution to the biological evaluation of cuban plants. Revista Cubana de Medicina Tropical, 31, 29-35.

[6] Sundarrao K, Burrows I, Kuduk M, Yi YD, Chung MH, Suh NJ and Chang IM. (1993). Preliminary screening of antibacterial and anti-tumor activities of papuan new guinean active medicinal plants. Pharmaceutical Biology, 31, 3-6.

[7] Heinrich M, Kuhnt M and Wright CW, (1992). Parasitological and microbiological evaluation of mixed Indian medicinal plants (Mexico). Journal of Ethnopharmacology, 36, 81-5.

[8] Baskar R, Rajeswari V and Kumar TS. (2007). In vitro antioxidant studies in leaves of annona species. Indian Journal of Experimental Biology, 4, 480-5. 
[9] Antoun MD, Gerena L and Milhus WK (1993). Screening of the flora of Puerto-rico for potential antimalarial bioactives. International Journal of Pharmacology, 31, 255-8.

[10] Leboeuf M, Cavé A, Bhaumik P, Mukherjee B and Mukherjee R. (1980). The phytochemistry of the annonaceae. Phytochemistry, 21, 2783-2813.

[11] Kossouoh C, Moudachirou M, Adjakidje V, Chalchat JC and Figuérédo G. (2007). Essential oil chemical composition of Annona muricata L. Leaves from Benin. Journal of Essential Oil Research, 19, 307-309.

[12] Chang FR, Liaw CC and Lin CY. (2003). New adjacent bis- tetrahydrofuran annonaceous acetogenins from Annona muricata. Planta Medica, 69, 241-6.

[13] Mangal M, Khan MI and Agarwal SM. (2015). Acetogenins as potential anticancer agents. Anti-cancer agents in Medicinal Chemistry, 16(2), 138-159.

[14] Zeng L, Wu FE and Oberlies NH, (1996). Five new monotetrahydrofuran ring acetogenins from the leaves of Annona muricata. Journal of Natural Products, 59, 1035-42.

[15] Le Ven J, Schmitz-Afonso I, Touboul D, Buisson D, Akagah B, Cresteil T, Lewin G and Champy P. (2011). Annonaceae fruits and parkinsonism risk: metabolisation study of annonacin, a model neurotoxin; evaluation of human exposure. Toxicology Letters, 205:S50.

[16] Lannuzel A, Hoglinger GU, Champy P, Michel PP, Hirsch EC and Ruberg M. (2006). Is atypical parkinsonism in the carribean caused by the consumption of Annonaceae? Journal of Neural Transmission, 70(70), 153-157.

[17] Carparros-Lefebvre D and Elbaz A. (1999). Possible relation of atypical parkinsonism in the French West Indies with consumption of tropical plants: A case-control study. Lancet, 354(9175), 281-286.

[18] Arthur FK, Terlabi EO, Larbie C and Woode E. (2012). Evaluation of hepatoprotective effect of aqueous extract of Annona muricata (Linn.) leaf against carbon tetrachloride and acetaminophen-induced liver damage. Journal of Natural Pharmaceuticals, 3, 25-30.

[19] Escobar-Khondiker M, Höllerhage M, Muriel MP, Champy P, Bach A, Depienne C, Respondek G, Yamada ES, Lannuzel A and Yagi T. (2007). Annonacin, a natural mitochondrial complex I inhibitor, causes tau pathology in cultured neurons. Journal of Neuroscience, 27, 7827-7837.

[20] Champy P, Melot A, Guérineau Eng V, Gleye C, Fall D, Höglinger GU, Ruberg M, Lannuzel A, Laprévote 0 and Laurens A. (2005). Quantification of acetogenins in Annona muricata linked to atypical Parkinsonism in guadeloupe. Movement Disorders, 20, 1629-1633.

\section{How to cite this article}

Nweke EO and Akpuaka FC. (2019). The effect of ethanolic extract of Annona muricata leaf on the basal ganglia. GSC Biological and Pharmaceutical Sciences, 6(3), 40-44. 